\title{
Biculturalism and Multiculturalism: Competing Tensions in Visual Arts Education in Aotearoa-New Zealand
}

\author{
Jill Smith \\ The University of Auckland \\ New Zealand
}

New Zealand has become an increasingly multicultural society since the 1990s. But multicultural education is complicated in this nation by its position on biculturalism, a commitment founded in its postcolonial history. The finding of an investigation in secondary schools, which showed that national and visual arts curricula emphasize biculturalism over multiculturalism, was reflected in art teachers' pedagogies. In this paper I discuss how multicultural art education could be strengthened within the existing bicultural framework. Bridging the gap between policies and practices would require art teachers to review their practices and implement strategies which take into account the cultural diversity of students to enhance understandings of their own and other multicultural societies.

\author{
Locating Aotearoa-New Zealand: A Bicultural Context \\ Cultural Policy in National Curricula: A Bicultural Emphasis \\ Contextualizing the Research \\ Art Teachers' Interpretations of National Curricula \\ Understandings of Multiculturalism and Multicultural Pedagogies \\ Bridging the Gap between Policy and Practice \\ Notes \\ References
}

Since the 1990s New Zealand has become an increasingly multicultural society. With a population of just over four and a half million people, it is now home to the indigenous Maori, European/Pakeha ${ }^{1}$, a rich diversity of Pacific and Asian peoples, and many newcomers from around the world. The student population has become progressively diverse, particularly in my professional location, Auckland, a city in which $40 \%$ of secondary schools are classified as multicultural (Education Review Office, 2000; Ministry of Education, 2008; Statistics New Zealand, 2006). However, multicultural art education in New Zealand secondary schools is complicated by this nation's position on biculturalism, a commitment founded in its postcolonial history (Hill, 2004, 2010; May, 2002; Salmond, 1991). It became evident during fieldwork research in 
secondary schools that the differing emphases in cultural policy in the national curriculum affected the pedagogical practices of art teachers. In this paper I examine what I consider to be a unique and demanding circumstance - the issue of multicultural art education in the context of official biculturalism in New Zealand. I suggest that secondary school art teachers must take into account the increased ethnic diversity and cultural differences of students and that multicultural policies and practices should be strengthened within the bicultural framework (Bartley \& Spoonley, 2004; Durie, 2005; Hill, 2010). This will require a re-interpretation of national curricula in order to provide opportunities for students to learn about the nature of artistic expressions of self, community, and culture that are intended to recognize, value, and contribute to an understanding of the multicultural nature of New Zealand society, and beyond.

\section{Locating Aotearoa-New Zealand: A Bicultural Context}

Maori are the "tangata whenua," the people of the land. As the first voyagers to arrive by canoe over 1,000 years ago from Hawaiiki, the Pacific Islands of origin, they called New Zealand "Aotearoa"-the land of the long white cloud-referring to the cloud visible above the North and South Islands. In 1840 New Zealand became a British colony. Its founding document, Te Tiriti o Waitangi (the Treaty of Waitangi) enacted between Maori, the indigenous and an unconquered people, and the British Crown established the signatories as equal partners holding equal rights and privileges. Although the Treaty provided for protection of Maori and their natural and cultural resources, alienation of Maori land and rights occurred well into the $20^{\text {th }}$ century. Despite some evidence of often paternalistic, humanitarian attitudes, assimilation was overtly and covertly the prevailing policy (Hill, 2004, 2010; Kawharu, 1989). In the 1970s, however, national and international social movements created possibilities for Maori resistance. In a climate of liberal humanism, fostered by economic prosperity, the seeds of biculturalism were planted. In 1975, as a consequence of Maori pressure for affirmation of rights, the Treaty of Waitangi Act was passed by Parliament and the Waitangi Tribunal established to consider grievances arising from Maori relationships with the Crown (Orange, 1987). Although the precise interpretation of this declaration of equality and its legal status has been argued ever since, and the issues involved continue to create tensions in MaoriEuropean relations, Te Tiriti o Waitangi remains the defining document of New Zealand's nationhood.

\section{Biculturalism and Multiculturalism: Differing Perspectives}

In the 1970s, while other former British colonies were introducing multiculturalism as national policy, cross-cultural understanding in New Zealand was advocated in terms of biculturalism, with multiculturalism a hoped-for future 
outcome (Hill, 2010; Irwin, 1989). May (2002) argues that early attempts to promote multiculturalism were "rightly discarded for their potential to undermine prior and pre-eminent bicultural commitments to Maori as tangata whenua" ( $p$. 15). This emphasis contrasts with the position of other colonized peoples such as the indigenous Aboriginal in Canada and Australia. Irwin, Rogers and Farrell (1999) claim that the Aboriginal peoples in both nations are denied their rights as the original inhabitants of the land by multicultural policies in schooling, which reinforce the role of the dominant society in the education system. They describe multiculturalism as "an ideology or practice of the immigrants to these lands, which often ignores the unique position of the indigenous peoples" (p. 49). In their view, multicultural polices are "the products of immigrants and designed for other migrants" ( $p$. 56). The Aboriginal peoples, themselves, claim that multicultural policies limit their status to that of a small minority group, thereby threatening their cultural survival (Fleras \& Elliot, 1992). In contrast, Maori, a minority group in New Zealand, are protected by bicultural policy. For example, in 1986 the Waitangi Tribunal stated:

We do not accept that Maori is just another one of a number of ethnic groups in our community. It must be remembered that of all minority groups the Maori alone is party to a solemn treaty made with the Crown. None of the other migrant groups who have come to live in this country in recent years can claim the rights that were given to the Maori people by the Treaty of Waitangi (Waitangi Tribunal, 1986, cited in May, 2002, p. 37).

While antagonism towards group-based minority rights is debated worldwide, May (2002) and Hill (2010) draw attention to a distinctive feature in New Zealand, the division regularly drawn between biculturalism and multiculturalism by liberals and conservatives who oppose the politics of multiculturalism, but also by Maori. This raises the question of how competing claims of biculturalism and multiculturalism can be resolved or how, as Hill (2010) suggests, multiculturalism can be "fitted into" biculturalism. In the new millennium the voices have become more optimistic about ways of "accommodating multiculturalism" within a bicultural framework (Bartley \& Spoonley, 2004; Durie, 2005). Such optimism requires a shift in policy and practice to accommodate the demographic reality of New Zealand's increasingly multicultural society.

\section{European Teachers and Multicultural Students: A Widening Gap}

New Zealand is one of the highest migrant-receiving countries in the world (Singham, 2006). In its report, Multi-cultural Schools in New Zealand, the Education Review Office (2000) emphasized that a decline in the New Zealand European/Pakeha population was likely to continue and that there would be a corresponding increase in the numbers of Maori, Pacific, Asian, and students from other cultures in our schools. Although the latest census (Statistics New Zealand, 2006) confirmed that Europeans comprise $67.6 \%$ of the population, 
$14.6 \%$ identified as Maori, $9.2 \%$ as Asian (the fastest-growing group with an increase of $50 \%$ ), $6.9 \%$ identified as Pacific peoples (the second fastest-growing group, up $14.7 \%$ ), and $10.4 \%$ identified with more than one ethnic group. In some Auckland secondary schools up to $66 \%$ students are of Asian ethnicity (Smith, 2010b).

The report stressed that the predominantly European/Pakeha teaching community now works with student populations more diverse than when they began teaching. A survey of 80 heads of art departments in Auckland secondary schools showed that they are predominantly European/Pakeha $(83 \%)$ and female (76.6\%) (Smith, 2005). This outcome resonates with international research that school populations are becoming more diverse while teachers continue to be predominantly White and female (Landsman \& Lewis, 2006; Sleeter, 2001; Sleeter \& Grant, 2003). In 2010 the art teacher demographic in Auckland has not changed substantially since 2005 . There is a small increase in teachers of Maori and Pacific Island ethnicity and a growing number of teachers from Asian ethnic groups (Smith, 2010b).

\section{Cultural Policy in National Curricula: A Bicultural Emphasis}

Analysis of national curricula highlights the tension between biculturalism and multiculturalism. The significance for education is that policy is articulated foremost in terms of the partnership between Maori and European, reflecting the government's requirement to acknowledge the Treaty in the charters of publicly funded educational and cultural institutions. This emphasis is evident in The New Zealand Curriculum (Ministry of Education, 2007) which provides official policy for teaching, learning, and assessment in all schools. Although "cultural diversity" is cited as one of eight principles that embody beliefs about what is important and desirable in school curriculum, cultural policy is expressed in the first instance in terms of the partnership between European and Maori "that is at the core of our nation's founding document, Te Tiriti o Waitangi-the Treaty of Waitangi" (p. 6). The vision is for young people "who will work to create an Aotearoa New Zealand in which Maori and Pakeha recognise each other as full treaty partners and in which all cultures are valued for the contributions they bring" (p. 8).

This politically and ideologically driven "official biculturalism" (Smith, 2007b, 2010a) is encapsulated in parallel curriculum statements that inform the arts, including visual arts. Developed for use in Maori medium education, Nga Toi $i$ roto i te Mataraunga o Aotearoa (Ministry of Education, 2000a) is presented in te reo Maori (Maori language). Mane-Wheoki (2003) describes it as "a resolutely monocultural Maori arts curriculum statement, culturally specific to the indigenous people of New Zealand, and activated by a vision of 'tino rangatirotanga'..." (p. 81) ${ }^{2}$. He describes the mainstream document, The Arts in the New Zealand Curriculum (Ministry of Education, 2000b), as "both ideologically bicultural and culturally comprehensive and inclusive...to accommodate an increasingly multicultural student population, including those of 
the still-dominant Pakeha and the still-subordinate tangata whenua" (p. 81). Closer examination shows, however, that while the arts curriculum purports to be culturally inclusive, the requirements for learning in the four arts disciplines (dance, drama, music, and visual arts) are noticeably specific for the Maori dimension of the bicultural partnership. For example, learning in the arts includes:

- "Developing an understanding of art forms in relation to the tangata whenua, [and] to biculturalism in New Zealand..." (p. 7)... and that "toi Maori, the arts of the Maori, are integral to our sense of a distinctive, evolving national identity" (p. 9);

- "Appreciating the significance and value of toi Maori in different contexts, [and] developing understandings of the ideas and messages expressed in traditional art forms and contemporary developments" ( $p$. $11)$;

- "Developing literacies in Maori arts requires an understanding that aspects of reo, tikanga, and whakapapa are unique to the art forms and practices of particular iwi" (p.11).

The descriptors of achievement objectives and learning examples contain numerous references to Maori art forms. Implicit in the act of leaving Maori words untranslated is that teachers are expected to familiarize themselves with Maori language ${ }^{3}$. The final section of the curriculum focuses upon program implementation. Here it is stated (emphasis mine) that "Culturally Inclusive Programs" in the arts:

- Will provide opportunities for students to learn about the indigenous heritage of Maori;

- Must embrace the heritage of the tangata whenua;

- Will recognize that te reo Maori, toi Maori, and tikanga Maori have an important place in the arts education of all students in New Zealand ( $p$. 104).

Further analysis of the arts curriculum points to European art as the second cultural strand, albeit lacking the specificity of the Maori dimension. Mane-Wheoki (2003) claims this as an assumption that the predominantly European art-teaching community accepts that it is the "real" culture. Presented in terms of traditional fields, it is stated that students' conceptual thinking will be developed within a range of practices across drawing, sculpture, design, painting, printmaking, photography, and moving image. These fine arts forms, which became an integral part of the Western "canon," remain an enduring dimension of modernist culture, and the canon continues to be the dominant force in the majority of the world's formal art education systems (Crowther, 2007) ${ }^{4}$. The specification of these fields positions visual arts education in New Zealand firmly within the Eurocentric conception of the "fine arts." There is no reference to the marginalized forms of "popular arts," or other cultural manifestations such as 
craft, folk art, the decorative arts, applied arts, or tribal arts (Brottman, 2005; Chalmers, 1999; Crowther, 2007). Nor is there mention of such international trends as "visual culture" education (Duncum, 2009; Freedman \& Stuhr, 2004; Mason \& Eça, 2008) and "material culture" studies (Blandy \& Bolin, 2003).

Messages of cultural inclusiveness are included, but follow the statements of bicultural intent, and are generalized in comparison. Significantly, pedagogical direction for multicultural study is presented in the penultimate section of the arts curriculum (Ministry of Education, 2000b). Under the heading, "Culturally Inclusive Programs," it is stated (emphasis mine) that the arts:

- Will encourage positive attitudes towards cultural diversity;

- Will recognize the diversity of individual students within particular cultures;

- Will recognize that knowledge bases can be culturally diverse (p. 104).

The "will" of the toi Maori requirements applies to those listed under the heading for culturally inclusive programs. Four years after the publication of the arts curriculum, I investigated how it was being interpreted and implemented (Smith, 2005). That pilot study into relationships between the arts curriculum, changing student demographics, and content of art programs at years 9-10 (year levels which have the national curriculum in common), signalled that the art of "other" cultures had little influence on pedagogy. It provided the foundation for the research discussed below (Smith, 2007a), the findings of which prompted me to raise issues about multicultural art education in New Zealand.

\section{Contextualizing the Research}

The aim of the research was to investigate how art teachers' understandings of the ethnic diversity and cultural differences of students were reflected in their pedagogical practices in year 9-10 art programs (levels that have national curricula in common for 13-14 year olds), and to what extent those practices were shaped by personal and professional influences. The research problem lent itself to an interpretive paradigm; thus the process of interpretation and reinterpretation of the intentional, meaningful, and ordinary behavior of the art teachers was at the heart of the study (Denzin \& Lincoln, 2005; Punch, 2009; Stake, 2010). My decision to use the flexible methodology offered by a case study enabled me to gain through fieldwork, in a sample of secondary schools, a better understanding of a particular case within the context of education policy, curriculum, and pedagogy (Stake, 2006).

As is typical in qualitative inquiry, I focused in depth on a small sample selected purposively, not randomly (Denzin \& Lincoln, 2005). Five Auckland secondary schools, herein referred to as Schools A-E, were selected on the basis of cultural diversity, geographical spread, and school type. Three of the five-all large co-educational state schools-reflected New Zealand's 
increasingly multicultural society. School B comprised 1,800 students from 60 ethnic groups. In School C 1,000 students came from 57 countries, with nearly $50 \%$ originally from overseas. School E's population of 1,800 students included Asian (23\%), Maori (20\%), Pacific Islands (14\%), and European (43\%). The inclusion of two less culturally diverse schools was in response to claims that attention should be given to cultures regardless of whether or not they are represented in a school's population (Landsman \& Lewis, 2006; Sleeter, 2001). At School A, an integrated-state girls' school, $75 \%$ of 950 students were European. Of the 400 students at the private boys' school, School D, $80 \%$ were European.

The selection of 10 participants, the head of each art department and an assistant art teacher in each school, enabled me to gain a variety of perspectives within and between schools. The teachers, of whom eight were female, had been teaching from 2 - 24 years. Five identified as New Zealand European or Pakeha, the others as Maori, Taiwanese, Samoan, North American and New Zealand Dutch. My choice was influenced by claims that variables within the communities of students mean that a teaching force comprising the dominant cultural majority can no longer ignore the fact that "others" have an identity within the educational contexts of school, curriculum, and classroom (Bishop \& Berryman, 2006; Gay, 2000; Landsman \& Lewis, 2006; Sleeter \& Grant, 2003). Prior to the fieldwork, school principals, art teachers, 231 students, and the parents/caregivers of students under the age of 15 years (the majority) gave informed consent. New Zealand is a very small country; thus, every attempt was made through pseudonyms and disguised locations to protect the identity of teachers and schools.

Consistent with case study research, I collected data through multiple methods which did not privilege one over another (Denzin \& Lincoln, 2005; Stake, 2006). Document analysis, participant-observations, interviews, and photographic recording of year 9-10 students' art works were employed, with each method informing the other. Because documents are considered valuable for what lies behind them, their embedded meanings, and what they purport to say (Hodder, 2003), I scrutinized each school's charter and vision statement, art department scheme, and program planning for years 9 and 10 art, in the context of their student demographic. My decision to conduct three participantobservations with each teacher during a sequence of lessons with a year 9 or 10 class was inspired by Eisner's (1991) claim that "the richest vein of information is struck through direct observation of school and classroom life" (p. 195). The choice to interview teachers was influenced by exponents who consider the interview to be an essential, creative process and a highly interactive means of generating data (Eisner, 1991; Fontana \& Frey, 2003). Three semi-structured hour-long interviews with each teacher focused progressively upon their perspectives on cultural policy in the arts curriculum, personal and professional histories, knowledge of multicultural pedagogies, and perceptions of their own practices. These three methods were complemented by documentation of a representative sample of students' outcomes in progress and on completion. Analysis of such "material traces" provided important alternative insights 
(Hodder, 2003). Interviewing the 231 students was beyond the scope of the research. However, their role was taken into account in the observations and informal interactions during the observer-participant encounter. It was during these times that each student shared with me their ethnicity and cultural background.

Data analysis and interpretation began from the very first reading of schools' documents in order to inform subsequent observations and interviews (Stake, 2006). Field text made from notes and documents in the field became the research text, which was then re-created as a working interpretive document before becoming the published text (Denzin \& Lincoln, 2005). Trustworthiness was obtained by "structural corroboration," multi-method techniques, and analyst triangulation (Eisner, 1991). To make data comprehensible, analytic deduction was based on initial coding, identification of categories, and development of concepts or themes (Lichtman, 2006). A combination of explanatory, descriptive and expressive modes was used in the reporting (Punch, 2009; Stake, 2006, 2010) for which I carefully selected descriptive terms, quotes recorded in field notes and interview transcripts, and samples of students' art works to represent the art programs. A notable feature of the findings from each school was the close alignment between what the 10 teachers purported to do according to their art department schemes, program planning and verbal accounts, and what they actually did.

\section{Art Teachers' Interpretations of National Curricula}

It was evident from art department schemes, interview data, and classroom observations that the 10 art teachers, regardless of their ethnicities, gave priority to meeting bicultural imperatives. Each believed that the dual focus on Maori and European/Pakeha art and culture was a "required," not optional, dimension of visual arts education. Their interpretation reinforces Mane-Wheoki's (2003) view that "an insistent 'bicultural' vision continues to pervade the arts curriculum" in New Zealand (p. 8). Only one teacher, the head of art at School A, was not sympathetic to the emphasis on toi Maori and the requirement to understand aspects of reo, tikanga, and whakapapa:

I do teach Maori art units since it is an important part of New Zealand culture, and required by the curriculum, but I feel like it is tokenism because I am not directly of that culture and so my ability to teach it feels limited... if it wasn't "compulsory" then I would probably avoid teaching it where possible (cited in Smith, 2007a, p. 172).

Regardless of her discomfort, this teacher's Maori art units for year 9 and 10 students, and those of the other nine teachers, reflected their interpretation of how to provide opportunities for students to learn about the indigenous heritage of Maori as tangata whenua and to recognize that te reo Maori, toi Maori, and tikanga Maori have an important place in visual arts education for all students in 
New Zealand (Ministry of Education, 2000b). Art units invariably began with the curriculum strand, "understanding the visual arts in context," so that students could gain insights into the context/s, forms and significance of selected aspects of toi Maori, including relevant reo. Most often the Maori art component was part of a bicultural approach. For example, the art teacher at School $D$ focused on the theme of "cultural cloaks." In this unit year 9 students researched traditional and contemporary forms of kahu/cloak in both Maori and European art and culture as a springboard for developing ideas and making their own personal identity cloaks.

In contrast, the lesser prominence given to stated multicultural requirements in national curricula resulted in less emphasis in art programs. Although every teacher professed awareness of the multicultural focus for students to gain understanding of how and why individuals, communities, and societies make art works, opportunities for them to develop "deeper understandings of cultural traditions and practices in New Zealand and overseas" were interpreted predominantly in terms of the bicultural partnership (Ministry of Education, 2000b, p. 5). Some teachers downplayed multicultural imperatives because of the "crowded curriculum." Others spoke of the difficulty of "fitting all cultures" into their programs, a common sentiment in international literature on "myths" and "misconceptions" about multicultural education (Banks \& McGee Banks, 2010; Grant \& Chapman, 2008), and multicultural art education (Delacruz, 1995). Irrespective of the type of school they taught in, several teachers saw little need to include the cultures of "other" students in art units. The head of art at the multicultural School E, where $57 \%$ students were nonEuropean, professed to take little account of the cultural differences of students. At School A, where $75 \%$ of students were European, the head of art said:

I prefer not to teach about the art of other cultures because I feel like I know little about it and don't "own" it (cited in Smith, 2007a, p. 172).

The European dimension of the bicultural partnership was particularly evident in the choice of artists' works selected for students to research and use as inspiration for personal practice. Interviews, classroom observations, and students' work confirmed that "artist models" were drawn primarily from a modernist Western aesthetic. Students, no matter what their ethnicities, were given little encouragement to discover art works from their own heritage or culture. Although most teachers expressed no bias towards "high art," nor rejection of the so-called "low art" of popular culture, crafts, decorative arts, and tribal art, the artists and art works studied in 7 of the 10 programs conformed to definitions of art within the Western art canon. Reflecting the historical experiences of the teachers themselves, classical forms of antiquity and the development of Cubism were studied by year 10 students in two schools and the conventions of portraiture in a further three. In most instances emphasis was on the art forms as self-sufficient products, rather than their underlying social, political, and cultural contexts.

A move beyond the bicultural emphasis was largely confined to the art of Pacific Island nations. Auckland, known as "the Polynesian capital of the world," 
is home to $67 \%$ of Pacific peoples in New Zealand, with some schools having up to $90 \%$ Pacific Island students (Ministry of Education, 2008). Every teacher included a program with a Pacific focus. However, these comprised three types of study: the material art forms of Pacific peoples, symbols and patterns which could be considered cultural stereotypes of particular ethnic groups, or the work of individual contemporary artists. In contrast to the bicultural units, study of the underlying cultural significance of Pacific Islands' art forms was minimal. Of more concern, the stated aims in the curriculum for visual arts education "to encourage positive attitudes towards cultural diversity" and "to recognize the diversity of individual students within particular cultures" was not apparent in planning or teaching (Ministry of Education, 2000b, p. 104). Study of the art and cultures of the ethnically diverse and culturally different students in the fieldwork schools was not a significant factor. The Samoan art teacher in School A confirmed that multiculturalism was not being addressed:

We're still not open to that as a school... it's not at the forefront ... Asian or Indian or other students would not have an opportunity to draw on their cultures ... (cited in Smith, 2007a, p. 167, p. 169).

The art teacher in School C, alone, suggested that although the arts curriculum "is trying to expand culturally, it doesn't embrace other than Maori or Pacific Island culture" (p. 225). Her interpretation of the curriculum reflected the position of most teachers. Their focus was upon the statements of bicultural intent. It was apparent from the fieldwork that "difference" was allowed to exist and be practiced at the margins, but not at the "front and center" (Nieto, 2000, p. 180).

\section{Understandings of Multiculturalism and Multicultural Pedagogies}

It was clear from the interviews that the art teachers' understandings of "multiculturalism" were conceptualized primarily in terms of the "ethnic diversity," rather than cultural differences of students. Although the head of art at School B said that the art teachers in her department were "particularly aware of the 60 different ethnic groups at the school" (cited in Smith, p.189), she, like the others, seemed unaware that ethnic descriptors can be "disguised" as cultural definitions (May, 1999, p. 12) and that such a simplistic interpretation of multiculturalism is inadequate (Nieto, 2004). A noticeable feature of the fieldwork was the teachers' use of collective nomenclatures: for example, "Pacific Island" for students who identified [individually to me during class] as Samoan, Tongan, Cook Island, Niuean or Fijian. Similarly, differences between students from Asian ethnic groups were not identified. Overall, the teachers seemed unaware that "diversity," let alone "difference," is an essential dimension of multicultural curriculum (Sleeter \& Grant, 2003). Only the European art teacher in School D professed to have some awareness of multicultural theories, though she also expressed a view common among others: 
I have little knowledge of theory, except for an awareness of multiculturalism. The most important thing for me is adapting to the school environment every year and just responding to the individual needs of the kids we have (cited in Smith, 2007a, p. 198).

The other nine teachers professed no conscious knowledge of multicultural pedagogies which focus on celebrating cultural pluralism, affirming diversity and fostering cultural difference (Nieto, 2004, Sleeter, 2010). Nor was any knowledge cited of pedagogies which emphasize equity and justice and which focus on inequitable power relationships among groups (Nieto, 2004; Sleeter \& Grant, 2003; Grant \& Sleeter, 2007). Seminal publications on multicultural art education (Boughton \& Mason, 1999; Chalmers, 1996) were unknown to the teachers. The head of art at School D said she did not actively read and was "too pragmatic for theory" (p. 198).

Cultural inclusion, where it occurred, was interpreted by the teachers in terms of assimilationist pedagogies identified by Sleeter and Grant (2003). Illustrative of the "human relations approach," the head of art at School E looked for cultural events around which to design a unit. Students made Chinese lanterns to coincide with the Chinese Lantern Festival or rangoli patterns to represent the Hindu Diwali Festival of the Lights. Such activities are not uncommon in other countries. Begler (1998) refers to the superficial fixation in classroom studies of culture in the United States which focus on the "Five 'F's food, fashion, fiestas, folklore and famous people" (p. 272). Similarly, Chalmers (1996) considers the human relations approach as a "totem-poles-out-of-toiletrolls model" (p. 46). These approaches raise the question of how "simple additions to ethnic content" can be replaced by deeper understandings of cultural differences if multiculturalism is to be more than an examination of "ethnic art" (Nieto, 2004, p. 92).

The most common scenario in the fieldwork schools was in programs which teachers claimed gave students opportunity to express their "individual identity." In six classrooms students used universal, cultural, and personal symbols to represent themselves, predominantly through traditional selfportraiture. At School C, where the population was largely immigrant, a year 9 class depicted aspects of their cultural and transnational backgrounds through nationalistic identifiers such as kangaroos, eagles, pandas, and sheep. Although the teachers considered these approaches to be "multicultural," such tokenism did little to promote students' understanding of each other or of others' cultures. Similarly, when students at School E collaboratively expressed the "popular cultural iconography" of New Zealand in making "kiwiana" chairs, there was no critical examination of popular forms of visual culture in a socio-cultural context (Duncum, 2009; Freedman \& Stuhr, 2004; Mason \& Eça, 2008) ${ }^{5}$.

All ten art teachers were unaware of discourses on critical pedagogy which raise questions about the relationships between the margins and centers of power in schools, which attempt to create new forms of knowledge through breaking down disciplines and creating interdisciplinary knowledge and which reject the distinction between high and popular culture in order to make 
curriculum knowledge responsive to the everyday knowledge that constitutes peoples' lived histories differently (Freire, 1985; Giroux, 1994). Culture as a political issue in education and schooling was not referred to in art department documentation nor, in response to my questions, expressed as a relevant concern. Neither was the politics of culture-the way in which curricula reflect cultural forces that are the outcome of competing interests of stakeholders-a dimension of their pedagogical practices. The pedagogical practices observed aligned with Hattie's (2003) assertion that "educators still make most of their practice decisions on the basis of personal belief and personal experience" ( $p$. 12). The teachers believed their programs were driven by a sincere concern for the welfare of students and designed in their interests. Planning and teaching were based largely on teachers' beliefs about what constituted appropriate visual arts education and on the broader social conditions and educational experiences that had shaped their practice. Most had attended tertiary art institutions, populated by predominantly European students, which promoted art forms within the Western aesthetic. Overall, the nature of art education offered by these ten teachers, notwithstanding the quality of art works students produced, maintained an emphasis on modernist art exemplars and promoted a bicultural position. In combination, these factors produced a form of art education whose curriculum policy, content, and pedagogical practices remained rooted in a predominantly monocultural and bicultural ethos.

\section{Bridging the Gap between Policy and Practice}

In this paper I have discussed bicultural policy in national curricula, arising from New Zealand's founding Treaty and its powerful influence on art teachers' practices. I have shown that while student populations in secondary schools are increasingly diverse, art teachers interpreted the curriculum in ways that gave priority to the Maori and European/Pakeha partnership and less attention to curriculum directives which encourage culturally inclusive programs. I contend that bridging the gap between bicultural and multicultural policies and practices in visual arts education in New Zealand is not insurmountable. It does, however, require commitment and action on the part of art teachers. With recognition of Maori as tangata whenua (the first people of the land), and official biculturalism likely to remain, Hill's (2010) advocacy of cultural rights for all is timely:

The difficulties inherent in the interactions between biculturalism, multiculturalism, and the Treaty of Waitangi can only be resolved by thoughts and deeds from within the communities and parties concerned, and through dialogue with each other and others (pp. 313-314).

Dialogue with, and between, art teachers and their communities is vital for serious consideration of how multiculturalism can be strengthened within the bicultural framework. This will require all art teachers, including the predominantly European/Pakeha, to develop the same level of personal and professional understanding, confidence, and competence in using multicultural 
pedagogies as were shown for the bicultural (toi Maori and European) dimension of curricula. A first step would require critical self-review. It is likely that the European/Pakeha teachers in my research represent many others whose understandings of diversity and difference are balanced, even overpowered, by the potent influences of their Europeanized artistic and cultural inheritances. Even the five teachers of "other" cultures maintained that their pedagogical practices remained predominantly within Western traditions. The question has been raised in New Zealand as to whether teachers are sufficiently willing to be held accountable and face up to a responsibility to cater for cultural difference in classrooms (Bishop \& Berryman, 2006). A useful starting point for teachers is to recognize the reality of their personal and professional states of cultural knowledge (Smith, 2010a) and to acquire knowledge of the kaleidoscope of background experiences of their culturally diverse students. Nieto (2004), for example, claims that while culture is one of the differences students bring to school, "teachers' pedagogy is also influenced by their lack of knowledge concerning the diversity of their students" (p. 107). She asserts that "teaching from the point of view of students is uncommon... (and) that many teachers attempt to treat all students in the same way...." One strategy is for art teachers to place students' "differences" at the "front and center" of their practice (Nieto, 2000), rather than the curriculum policy driving pedagogy.

Given, however, that teachers in New Zealand accept employment on the understanding that they will deliver curriculum laid down by government statute, art teachers cannot ignore it. A second step would be to critically review their interpretation of the curriculum in ways that will recognize not only ethnic diversity but the cultural hybridity of individual students in today's world. I contend that although current curricula emphasize biculturalism there is room for teachers to "use" the curriculum to implement art teaching strategies through which students can notice and be sensitive to art and artists from ethnic and cultural groups other than their own, challenge their assumptions about people who seem different, and encourage students to ask questions that increase their understanding of another person's experiences and points of view (Chalmers, 2003).

This would require a shift from modernist progressivist pedagogy to critical (postmodern) pedagogies which specify inclusion and access and which affirm diversity and acknowledge difference as a dynamic conception of culture. Education, as advocated by Freire (1985) and Giroux (1994), is seen as a vital agency for informing people of the realities of ethnic diversity and cultural difference and the necessity for equity of achievement rather than mere equity of opportunity. In this context, art education theorists argue that the very visibility of art, as well as its function as a metaphor for culture, can play a significant educational role (Duncum, 2009; Freedman \& Stuhr, 2004; Mason \& Eça, 2008). Art education is an ideal vehicle through which teachers can provide opportunities for all students to find their "voice," and to gain understanding of the voices of others. It requires commitment to culturally responsive pedagogies which challenge the hegemonic knowledge perpetuating the power of the dominant cultural group (Gay, 2000). Such strategies are necessary to bridge the 
gap between policy and practice in art education in secondary schools in Aotearoa-New Zealand. Above all, they would place all students at the center, and not at the margins.

\section{Notes}

1. Following the arrival of European navigators, traders, and missionaries in the 1760s, Maori applied the descriptive term "Pakeha" (white man or abnormal skin colour) to these strangers and adopted the term "Maori" (normal or natural) for themselves (Walker, 1973).

2. The words "tino rangatirotanga" are used in Te Tiriti o Waitangi-the Treaty of Waitangi (1840) to denote "absolute sovereignty"- the power to make and enforce laws in Aotearoa.

3. Teachers are expected to learn basic reo (Maori language), including such terms as tikanga Maori (Maori cultural values) whakapapa (origins, genealogy), and iwi (tribes).

4. The Western "canon" is a canon of books, music, and art that is thought to have been highly influential in shaping Western culture. Bloom (1994) is one of the greatest defenders of the canon which mostly consists of Dead White European Males (DWEM) (Chalmers, 1999). Banks (1994) claims that it is the norm or standard that operates as a basis for educational criticism and evaluation.

5. From the 1930s the impulse to develop a national identity resulted in the populist arts conferring identity through nationalistic iconography and paraphernalia, referred to as "kiwiana." Based on the native kiwi bird, the term "kiwi" has become synonymous with New Zealanders themselves.

\section{References}

Banks, J. A. (1994). Multicultural education: Theory and practice ( $3^{\text {rd }}$ ed.). Boston: Allyn \& Bacon.

Banks, J. A., \& McGee Banks, C. A. (Eds.). (2010). Multicultural education: Issues and perspectives (7th ed.). Hoboken, NJ: John Wiley \& Sons.

Bartley, A., \& Spoonley, P. (2004). Constructing a workable multiculturalism in a bicultural society. In M. Belgrave, M. Kawharu \& D.V. Williams (Eds.), Waitangi revisited: Perspectives on the Treaty of Waitangi (2nd ed., pp. 136-148). Auckland, NZ: Oxford University Press.

Begler, E. (1998). Global cultures: The first steps towards understanding. Social Education, 62(5), 272-275. 
Bishop, R., \& Berryman, M. (2006). Culture speaks: Cultural relationships and classroom learning. Wellington, NZ: Huia.

Blandy, D., \& Bolin, P. (2003). Beyond visual culture: Seven statements of support for material culture studies in art education. Studies in Art Education, 44(3), 246-263.

Bloom, H. (1994). The Western canon: The books and the school of ages. New York: Harcourt Brace.

Boughton, D., \& Mason, R. (Eds.) (1999). Beyond multicultural art education: International perspectives. New York: Waxmann.

Brottman, M. (2005). High theory/Low culture. New York: Palgrave Macmillan.

Chalmers, F. G. (1996). Celebrating pluralism: Art, education, and cultural diversity. Los Angeles, CA: The J. Paul Getty Trust.

Chalmers, F. G. (1999). Cultural colonization and art education: Eurocentric and racist roots of art education. In D. Boughton \& R. Mason (Eds.), Beyond multicultural art education: International perspectives (pp.173-184). New York: Waxmann.

Chalmers, F. G. (2003). Dragon boats and other waka: Implications for art education in Aotearoa New Zealand. In E. Grierson \& J. Smith (Eds.), Nga waka, Aotearoa New Zealand Association of Art Educators refereed conference proceedings, 1(1), (pp. 257-274). Wellington, NZ: ANZAAE.

Durie, E. T. (2005). The rule of law, biculturalism and multiculturalism. Paper presented at the Australasian Law Teachers Association Conference (ALTA), University of Waikato, Hamilton, New Zealand, July 2005.

Crowther, P. (2007). Defining art, creating the canon: Artistic value in an era of doubt. Oxford, UK: Oxford University Press.

Delacruz, E. M. (1995). Multiculturalism and art education: Myths, misconceptions, misdirections. Art Education, 48(3), 57-61.

Denzin, N. K., \& Lincoln, Y. S. (2005). The Sage handbook of qualitative research (3rd ed.), Thousand Oaks, CA: Sage.

Duncum, P. (2009). Visual culture in art education. Visual Arts Research, 35(1), 64-75.

Education Review Office. (2000). Multi-cultural schools in New Zealand. Wellington: Government Printer.

Eisner, E. W. (1991). The enlightened eye: Qualitative inquiry and the enhancement of educational practice. New York: Macmillan.

Fleras, A., \& Elliot, L. (Eds). (1992). Forging unity from diversity: Multiculturalism as policy in Canada. In A. Fleras \& L. Elliott, Multiculturalism in Canada: The challenge of diversity (pp. 68-92). Scarborough, Ontario: Nelson. 
Fontana, A., \& Frey, J. (2003). The interview: From structured questions to negotiated text. In N. Denzin \& Y. Lincoln, Collecting and interpreting qualitative materials $\left(2^{\text {nd }}\right.$ ed., pp. 61-106). Thousand Oaks, CA: Sage.

Freedman, K., \& Stuhr, P. (2004). Curriculum change for the $21^{\text {st }}$ century: Visual culture in art education. In E. W. Eisner \& M. D. Day (Eds.), Handbook of research and policy in art education (pp. 815-828). Mahwah, NJ: Lawrence Earlbaum Associates.

Freire, P. (1985). The politics of education: Culture, power and liberation. London: Macmillan.

Gay, G. (2000). Culturally responsive teaching: Theory, research and practice. New York: Teachers College Press.

Giroux, H. A. (1994). Insurgent multiculturalism and the promise of pedagogy. In D. T. Goldberg (Ed.), Multiculturalism: A critical reader (pp. 325-343). Cambridge, MA: Blackwell.

Grant, C. A., \& Chapman, T. K. (2008). History of multicultural education, volume 2: Foundations and stratifications. New York: Routledge.

Grant, C., \& Sleeter, C. (2007). Doing multicultural education for achievement and equity. London: Routledge.

Hattie, J. (2003). New Zealand education snapshot: With specific relevance to the years 1-13. Paper presented at The Knowledge Wave 2003, The Leadership Forum, Auckland.

Hill, R. S. (2004). State authority, indigenous autonomy: Crown-Maori relations in New Zealand/Aotearoa 1900-1950. Wellington, NZ: Victoria University Press.

Hill, R. S. (2010). Fitting multiculturalism into biculturalism: Maori-Pasifika relations in New Zealand from the 1960s. Ethnohistory, 57(2), 291-319.

Hodder, I. (2003). The interpretation of documents and material culture. In N. Denzin \& Y. Lincoln, Collecting and interpreting qualitative materials $\left(2^{\text {nd }}\right.$ ed., pp. 155-175). Thousand Oaks, CA: Sage.

Irwin, K. (1989). Multicultural education: The New Zealand response. New Zealand Journal of Educational Studies, 24(1), 3-18.

Irwin, R. L., Rogers, T., \& Farrell, R. (1999). Multiculturalism denies the realities of Aboriginal art and culture. In D. Boughton \& R. Mason (Eds.), Beyond multicultural art education: International perspectives (pp. 49-64). New York: Waxmann Munster.

Kawharu, H. (1989). Waitangi: Maori and Pakeha perspectives of the Treaty of Waitangi. Auckland: Oxford University Press.

Landsman, J., \& Lewis, C. W. (Eds.). (2006). White teachers, diverse classrooms. Sterling, VA: Stylus. 
Lichtman, M. (2006). Qualitative research in education: A user's guide. Thousand Oaks, CA: sage.

Mane-Wheoki, J. (2003). Culturalisms and the arts curriculum. In E. M. Grierson \& J. E. Mansfield (Eds.), The arts in education: Critical perspectives from Aotearoa New Zealand (pp. 81-91). Palmerston North: Dunmore Press.

Mason, R., \& Eça, T. (Eds.). (2008). International dialogues about visual culture, education and art. London: Intellect.

May, S. (Ed.). (1999). Critical multiculturalism: Rethinking multicultural and antiracist education. London: Falmer Press.

May, S. (2002). Accommodating multiculturalism and biculturalism in Aotearoa/New Zealand: Implications for language teaching. Waikato Journal of Education, 8, 5-26.

Ministry of Education. (2000a). Nga Toi $i$ roto $i$ te Mataraunga o Aotearoa. Wellington, New Zealand: Learning Media.

Ministry of Education. (2000b). The arts in the New Zealand curriculum. Wellington, New Zealand: Learning Media.

Ministry of Education. (2007). The New Zealand curriculum. Wellington, New Zealand: Learning Media.

Ministry of Education. (2008). Education statistics for New Zealand, 2007. Wellington, New Zealand: Government Printer.

Nieto, S. (2000). Placing equity front and center: Some thoughts on transforming teacher education for a new century. Journal of Teacher Education, 51(3), 180-187.

Nieto, S. (2004). Affirming diversity: The socio-political context of multicultural education $\left(4^{\text {th }}\right.$ ed.). Boston: Allyn \& Bacon.

Orange, C. (1987). The Treaty of Waitangi. Wellington, New Zealand: Allen \& Unwin.

Punch, K. F. (2009). Introduction to research methods in education. London: Sage.

Salmond, A. (1991). Two worlds: First meetings between Maori and Europeans. Auckland, New Zealand: Viking.

Singham, M. (2006). Multiculturalism in New Zealand - the need for a new paradigm. Aotearoa Ethnic Network Journal, 1(1), 33-37.

Sleeter, C. E. (2001). Preparing teachers for culturally diverse schools: Research and the overwhelming presence of whiteness. Journal of Teacher Education, 52(2), 94-106.

Sleeter, C. E. (2010). Probing beneath meanings of multicultural education. Multicultural Education Review, 2(1), 1-24. 
Sleeter, C. E., \& Grant, C. A. (2003). Making choices for multicultural education: Five approaches to race, class and gender. New York: John Wiley \& Sons.

Smith, J. (2005). Survey research report: Visual arts education - Investigating curriculum content in Auckland secondary schools programmes at years 9-10. Unpublished report, The University of Auckland.

Smith, J. (2007a). Art education in New Zealand: Issues of culture, diversity and difference. Unpublished Doctor of Education Thesis, University of Auckland, Auckland. Retrieved from http://hdl.handle.net/2292/3171

Smith, J. (2007b). A case study: The dilemmas of biculturalism in education policy and visual arts education practice in Aotearoa-New Zealand. In T. Townsend \& R. Bates (Eds.), Handbook of teacher education: Globalisation, standards and professionalism in times of change (pp. 479493). The Netherlands: Springer.

Smith, J. (2010a). Teaching about indigenous forms of knowledge: Insights from non-indigenous teachers of visual arts education in New Zealand. In O. Kwo (Ed.), Teachers as learners: Critical discourse on challenges and opportunities (pp. 87-105). Hong Kong: Springer.

Smith, J. (2010b, in press). Understanding others: Asian students' perspectives on visual arts education in New Zealand, Australian Art Education.

Stake, R. (2006), Multiple case study analysis. New York: Guilford Press.

Stake, R. (2010). Qualitative research: Studying how things work. New York: Guilford.

Statistics New Zealand. (2006). Quickstats about New Zealand's population and dwellings. Retrieved July, 12, 2004 from http://www.stats.govt.nz/census/default.htm

Walker, R. (1989). Maori identity. In D. Novitz \& B. Willmott (Eds.), Culture and identity in New Zealand (pp. 35-52). Wellington: Government Printer. 